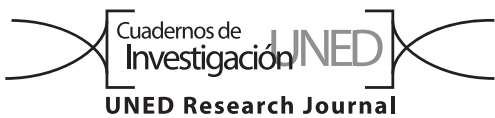

\title{
In vivo enzyme activity and induction of DNA damage in Swiss albino male mice by automobile waste leachate
}

\author{
Abass Toba Anifowoshe', Oluyinka Ajibola lyiola', Temitope Fatima Olafimihan'², Segun Olayinka Oladipo ${ }^{3}$, \\ Sunday Frank Yakubu' ${ }^{1}$, Thuwaibat Oyiyoza Abubakar' ${ }^{1}$, Rukayat Ifedolapo Bakare ${ }^{2}$, Kehinde Monica Akinseye ${ }^{4}$ \\ \& Faoziyat Adenike Sulaiman ${ }^{5}$
}

1. University of Ilorin, Faculty of life sciences, Department of Zoology, Cell Biology and Genetics Unit, llorin, Nigeria; anifowoshe.at@unilorin.edu.ng

2. University of Ilorin, Department of Zoology, Ecology and Environmental Biology Unit, Ilorin, Nigeria

3. Kwara State University, Department of Bioscience \& Biotechnology, Zoology Unit, Malete, Nigeria

4. Adeyemi College of Education, Department of Biology, Ondo, Ondo State, Nigeria

5. University of Ilorin, Faculty of Life Sciences, Department of Biochemistry, Ilorin, Nigeria

Received 30-XI-2017 • Corrected 19-II-2018 • Accepted 12-III-2018

\begin{abstract}
The rapid growth of motor vehicles use, together with poor waste disposal, produce environmental and biological threats. We evaluated the genotoxicity and enzyme activity of simulated automobile waste leachate in Swiss albino male mice (Mus musculus). Four mice per group were intraperitoneally treated with four leachate concentrations $(10 \%, 15 \%, 20 \%$ and $25 \% \mathrm{v} / \mathrm{v}$ : simulant (IOASL)/distilled water), as well as a negative control ( $0.5 \mathrm{~mL}$ UILSL); and a positive control (cyclophosphamide $20 \mathrm{mg} / \mathrm{Kg}$ body weight) for five consecutive days. There was a concentration-dependent increase in sperm abnormality compared to the negative control (except at $10 \%$ and $15 \% ; p<0,05$ ). Heavy metal ( $\mathrm{Pb}, \mathrm{Cd}, \mathrm{As}, \mathrm{Hg}, \mathrm{Cr}, \mathrm{Cu}, \mathrm{Fe}$ and $\mathrm{Zn}$ ) exceeded permissible limits for waste water. Significant variability was also recorded in liver serum enzyme activity (AST, ALP, ALT and ALB) and in the frequencies of micronuclei $(p<0,05)$. The interaction of some of these components with the genetic constitution of the cell during spermatogenesis might be responsible for the abnormalities.
\end{abstract}

Key words: automobile waste leachate, micronucleus, enzyme activities, sperm morphology, Ipata Oloje.
RESUMEN: Actividad enzimática in vivo e inducción de daño en el ADN en ratones machos albinos suizos por lixiviación de desechos de automóviles. El rápido crecimiento del uso de vehículos automotores, junto con la eliminación deficiente de residuos, producen amenazas ambientales y biológicas. Evaluamos la genotoxicidad y la actividad enzimática del lixiviado de residuos de automóviles en ratones machos albinos suizos (Mus musculus). Cuatro ratones por grupo fueron tratados por vía intraperitoneal con cuatro concentraciones de lixiviados (10\%, $15 \%, 20 \%$ y $25 \%$ v/v: simulante(IOASL)/agua destilada), como control negativo $(0,5 \mathrm{~mL}$ UILSL); y un control positivo (ciclofosfamida $20 \mathrm{mg} / \mathrm{Kg}$ de peso corporal) durante cinco días consecutivos. Hubo un aumento dependiente de la concentración en la anormalidad del esperma en comparación con el control negativo (excepto al $10 \%$ y $15 \%$, $\mathrm{p}<0,05)$. El metal pesado ( $\mathrm{Pb}, \mathrm{Cd}, \mathrm{As}, \mathrm{Hg}, \mathrm{Cr}, \mathrm{Cu}, \mathrm{Fe}$ y $\mathrm{Zn}$ ) excedió los límites permisibles para las aguas residuales. También se registró una variabilidad significativa en la actividad enzimática del suero hepático (AST, ALP, ALT y ALB) en las frecuencias de micronúcleos $(p<0,05)$. La interacción de algunos de estos componentes con la constitución genética de la célula durante la espermatogénesis podría ser responsable de las anomalías.

Palabras clave: lixiviados de residuos de automóviles, micronúcleos, actividades enzimáticas, morfología de los espermatozoides, Ipata Oloje.
One of the major problems of developing countries is waste disposal. Sometimes, waste is disposed into water bodies and around riverbanks, in gullies excavated by erosions and human activities, in gutters and channels constructed for flooding and burning on major roads. These disposal methods are capable of releasing hazardous substances into the environment which can endanger the survival of living organisms including human (Alimba, 2013). During disposal and processing of solid wastes in landfills and dump sites, they undergo a combination of physical, chemical and microbial processes (Christensen et al., 2001). These processes transform the solid wastes into different water-soluble compounds and particulate matter which can be transferred from the 
wastes to the percolating water (Bjerg et al., 2003). The contaminant-rich aqueous solution of pollutants formed is termed "leachate". The source of the percolating water may include precipitation, irrigation, surface run-offs, ground-water intrusion and the initial moisture content present within the wastes (El-Fadel, Findikakis \& Leckie, 1997). Metals could also leach out and in sloppy areas, are carried by acid water downstream or run-off to the sea (Duruibe, Ogwuegbu \& Egwurugwu, 2007). They may then be stored in river bed sediments or seep into the underground water thereby contaminating water from underground sources, particularly wells, and the extent of contamination depends on the proximity of the source's site (Peplow, 1999).

A group of hazardous pollutants which unavoidably pose a serious threat and concern to man and his environment is the automobile wastes e.g. spent oil, metal scraps and parts of automobiles, plastic and rubber components, emission from fuel engine; a large number of vehicle exhaust are carbon dioxide and water, nitrogen and oxygen (in diesel exhaust), soot (mostly in diesel exhaust), a large number of hydrocarbons with oxygen and nitrogen, and sulphur dioxide (in diesel exhaust). According to Bakare, Alimba and Alabi, (2013a), the contaminant rich aqueous solution of pollutants is called leachates and it contain chemicals and element like lead $(\mathrm{Pb})$, iron (Fe) benzene $\left(\mathrm{C}_{6} \mathrm{H}_{6}\right)$, sulphuric acid $\left(\mathrm{H}_{2} \mathrm{SO}_{4}\right)$ and nitrogen dioxide $\left(\mathrm{NO}_{2}\right)$ (European Commission, 2002; Oshode, Bakare, Adeogun, Efuntoye \& Sowunmi, 2008). The heavy metals found in waste have toxic effect on animals and can undergo bioaccumulation and biomagnifications (European Commission, 2002). The high concentration of these chemicals can cause severe degradation in the groundwater quality and palatability to human consumption (Bakare, Alabi, Gbadebo, Ogunsuyi \& Alimba, 2013b) especially to the households located close to the area. Alimba, Bakare and Aina (2012) also stated that the health of animal population exposed to chemical substances from waste is at risk and the population living close to these dumpsites, or those expose during open burning are easily affected (Emma, 2013).

It is a common practice in Nigerian cities and towns to allocate large tracts of land, sometimes reaching $5 \mathrm{Ha}$ or more, to groups of small scale auto-mechanic businesses and designate these as villages where they locate their workshops and repair yards to offer their services to the public; the larger the city, the larger the number of such mechanic villages contained in it. It is presumed that there are environmental and biological threats associated with this practice if not well managed (Adelekan \& Abegunde, 2011). This study examined the genotoxicity and enzymes activities effects of simulated automobile waste leachate from Ipata-Oloje mechanic workshop in llorin, Kwara state, Nigeria in Swiss albino male mice.

\section{MATERIALS AND METHODS}

Sampling Site: Ipata Oloje Jengbe in Ilorin West local government of Kwara State, $8^{\circ} 4807^{\prime} \mathrm{N}-4^{\circ} 5257^{\prime} \mathrm{E}$, Nigeria. It is a notable area in Ilorin known to accommodate all types of abandoned vehicle parts and car wastes. It has been in existed long ago but the documentation of its existence took effect in 1992.

Leachate Collection, Simulation and Preparation of Test Samples: The samples were collected at a depth of $0-10 \mathrm{~cm}$ using cleaned trowel. The samples were collected in 8 randomly selected points which include metal scraps and soil. Leachate simulation from the soil was carried out according to the American Society for Testing and Materials category A, extraction procedure as modified by Bakare, Oshode and Adelodun, (2007). Briefly, $200 \mathrm{~g}$ of the samples were grinded together, sundried for 24 hours and soaked in $2000 \mathrm{~mL}$ of distilled water for a period of 48 hours, filtered using a $15-\mathrm{cm}$ Whatman filter paper and sieved to remove debris. From the resultant stock solution (simulated leachate) of the automobile waste, the $\mathrm{pH}$ was measured and 10,0\%, 15,0\%, 20,0\%, and $25,0 \%(\mathrm{v} / \mathrm{v}$, simulant/distilled water) solutions were prepared and stored at $4^{\circ} \mathrm{C}$ until use based on standard procedure by Alabi, Omosebi and Chizea (2013). Soil sample from University of Ilorin, Ilorin was collected and used as a negative control to compare the analysis of the physicochemical parameters. The leachates were designated Ipata Oloje automobile simulated leachate (IOASL) and University of Ilorin simulated leachate (UILSL) respectively.

Biological materials: Twenty four (24) pathogen-free Swiss albino male mice (Mus musculus) (8-10 weeks old) weighing $(21-25 \mathrm{~g})$ were obtained from an inbred colony of the animal breeding unit of the Department of Physiology, University of Ibadan, Ibadan. They were acclimatized for 2-3 weeks in well-ventilated plastic cages in the animal house of the Department of Zoology, University of Ilorin, llorin. Under the same laboratory condition, commercial feed pellets purchased from Aromokeye Pharmacy, Ilorin, Kwara State, Nigeria and drinking water were made available ad libitum through the 35-day period of the experiment. Animals were cared for according to the standard guidelines (CIOMS, 1985) 
and the policy laid down by the Animal Ethics Committee of the University of Ilorin, Ilorin, Nigeria.

Physico-chemical and Heavy Metals Analysis: Total alkalinity, dissolved oxygen, biochemical oxygen demand (BOD), Chemical oxygen demand (COD), total dissolved solids (TDS), total suspended solute (TSS), salinity, conductivity, chlorides, nitrates, ammonia, and phosphates were analyzed in the leachate test samples in accordance with APHA (1998) method. Heavy metals such as Copper, Mercury, Arsenic, Lead, Cadmium, Chromium, Zinc and Iron were also analyzed in the samples in accordance with APHA (1998) and USEPA (1996) methods while the metal concentrations were measured using Spectrophotometer.

Experimental Design: Treatment were made up of six groups of animals, each group consisting of four mice $(n=4)$ of an average weight of $23 \pm 2$. Group 1, negative control received intra peritoneal injection of UILSL $(0,5 \mathrm{~mL} / \mathrm{mouse})$ for 5 consecutive days. Group 6 received intra peritoneal injection of cyclophosphamide (20mg/ $\mathrm{kg}$ body weight) for 5 consecutive days which served as the positive control. The remaining four groups, which served as the test groups were used and exposed to the samples of $10 \%, 15 \%, 20 \%$, and $25 \%$ test concentrations (IOASL) respectively. The test animals were exposed via intra-peritoneal injection of $0,5 \mathrm{~mL} /$ day per mouse of each concentration for five consecutive days and to the control groups. Cases of mortality were recorded. The mice were observed for 30 days, this is because spermatogenesis in mice takes about 35 days to complete and the animals were sacrificed by cervical dislocation followed by the surgical extraction of the caudal epididymis (Bartke, Weir, Mathison, Robertson \& Dalterio, 1974).

Assay of Sperm Abnormality: A standard procedure of Bakare et al. (2016) was employed for the sperm assay with slight modification. Briefly, mice of each category $(n=3)$ were sacrificed by cervical dislocation and the caudal epididymis were removed and transferred to $2 \mathrm{~mL}$ buffered physiological saline (normal saline). Sperm suspensions were prepared for each group by mincing each caudal epididymis in a mixture of normal saline and $1 \%$ Eosin $\mathrm{Y}\left(\mathrm{H}_{2} \mathrm{O}\right)$ at ratio 9:1 and allowed to stand for $45 \mathrm{~min}$, after which smears were made on dry clean glass slides; two smears per epididymis were made, and allowed to dry in air. For each suspension, 500 sperms i.e. 250 per slide were examined at 1000 folds magnification of oil immersion objective; a total of 3000 sperm were thus examined per group. The morphology of the sperm cells of the negative control group was compared with that of the treated concentrations as well as the positive control group.

Micronucleus Assay: Blood was collected from the tail. Two slides each from three mice per group were prepared and a thin smeared of blood was made to allowed them air-dry overnight in a dust free environment. The dried slides were then fixed in absolute methanol for 20minutes and allowed to dry overnight. The fixed smears were stained in 10\% May-Grunwald and 5\% Giemsa stains respectively (Fenech et al., 2003) after which the stained slides were rinsed with distilled water to remove excess stain. The slides were analysed for MN and nuclear abnormalities at 1000 using Olympus microscope. 500 cells were scored per slide (Carrassco, Tilbury \& Myers, 1990). Photomicrographs were taken with Samsung digital camera (F2.5 Bright lens; 16 Mega pixels) and edited with Microsoft office picture manager

Biochemical Assay: $2 \mathrm{~mL}$ of blood was collected immediately after cervical dislocation through cardiac punctured; and the liver was also collected from the animals for the biochemical assays. The livers were preserved in 0,25 molar of sucrose solution. The activities of Alanine aminotransferase (ALT), Aspartate aminotransferase (AST), Alkaline Phosphatase (ALP) and Albumin (ALB) in both liver and sera were determined using diagnostic kits (Quimica Clinica Applicada, S.A. Spain) and was carried out in Chemical pathology laboratory of the University of Ilorin, Teaching hospital following the methods by Doumas Watson and Biggs (1971).

Statistical Analysis: The SPSS software statistical package version (SPSS 16.0) was applied to evaluate the sperm abnormalities, micronucleus \& nuclear abnormality, enzymes activities and the differences between the negative, positive and test control groups. The differences were analysed by comparing them with the use OneWay ANOVA and the level of statistical significance were estimated at $\mathrm{P}<0,05$ using the Duncan Multiple Range (DMRT) test. The results were presented as (mean \pm standard error of mean) for each leachate sample.

\section{RESULTS}

Physico-Chemical Parameter Assessment: The result of the physicochemical parameters and heavy metals in the leachate test sample from the sampling site are presented in Table 1. The simulated sample was dark 
TABLE 1

Physico-Chemical Assessment of the Leachate test samples from IOASL in mice

\begin{tabular}{ccccccc} 
Parameter & UILSL & IOASL & NESREA & FEPA & USEPA & WHO \\
pH value & 7,06 & 8,34 & $6,0-9,0$ & $6-9$ & $6,5-8,5$ & $6,5-8,5$ \\
DO & 99,10 & 72,00 & - & - & - & - \\
Nitrates & 1,30 & 16,80 & 10,00 & - & 10,00 & - \\
$\mathrm{NH}_{4} \mathrm{~N}$ & 0,01 & 6,18 & 10,00 & 0,01 & 0,02 & - \\
Alkalinity & 30,00 & 152,00 & 150 & 250,00 & 20,00 & - \\
BOD & 62,20 & 110,00 & 50,00 & 50,00 & - & - \\
$\mathrm{COD}$ & 64,00 & 130,00 & 90,00 & - & 410,00 & - \\
$\mathrm{TDS}$ & 52,01 & 85,60 & 500 & 2000 & 500,00 & - \\
Salinity & 34,55 & 164,20 & - & - & - & - \\
$\mathrm{TSS}$ & 33,50 & 104,00 & - & - & - & - \\
$\mathrm{EC}$ & 346,00 & 184,00 & - & - & - & - \\
$\mathrm{TS}$ & 88,00 & 196,00 & - & - & - & - \\
$\mathrm{Hg}$ & $\mathrm{ND}$ & 0,209 & - & 0,10 & - & 0,0001 \\
$\mathrm{As}$ & $\mathrm{ND}$ & 0,256 & - & - & 0,01 & 0,05 \\
$\mathrm{~Pb}$ & $\mathrm{ND}$ & 0,219 & 0,05 & 0,01 & 0,015 & 0,05 \\
$\mathrm{Cd}$ & $\mathrm{ND}$ & 0,702 & 0,2 & 0,05 & 0,05 & 0,01 \\
$\mathrm{Cr}$ & $\mathrm{ND}$ & 0,855 & 0,05 & - & 0,1 & - \\
$\mathrm{Zn}$ & $\mathrm{ND}$ & 0,649 & - & - & - & 5,00 \\
$\mathrm{Fe}$ & $\mathrm{ND}$ & 0,904 & - & 0,05 & 0,30 & 0,1 \\
$\mathrm{Cu}$ & $\mathrm{ND}$ & 0,608 & 0,5 & 0,03 & 1,3 & 1,00 \\
\hline
\end{tabular}

Units of the parameters are in $\mathrm{mg} / \mathrm{L}$ except for $\mathrm{pH}$ which has no unit and EC in uScm${ }^{3}$, ND: not detected; * IOASL: Ipata Oloje automobile simulated leachate; UILSL: University of Ilorin simulated leachate; FEPA: Federal Environmental Protection Agency (1991); USEPA: United State Environmental Protection Agency (2006); NESREA: National Environmental Standards and Regulation Enforcement Agency (2009).

brown in appearance and the $\mathrm{pH}$ value was within the stipulated standard limit by USEPA and FEPA. The alkalinity, BOD and COD of the leachate sample was higher than standard limit set for both drinking water and waste sample. $\mathrm{Pb}, \mathrm{Cr}, \mathrm{Cd}, \mathrm{Cu}, \mathrm{Fe}$, and $\mathrm{Hg}$ concentrations in the simulated automobile waste leachate were higher than the standard limit for the waste water.

Enzyme Activities in Blood and Liver: Clinical signs of toxicity such as brownish-dark skin colouration, sluggishness, skin abrasion, and rectal collapse, reduction in food and water intake were observed. The significant $(p<0,05)$ increase was recorded in the serum and liver ALT, AST and ALP activities in exposed groups of mice compared with the control and it was dose dependent (Fig. 1). Only $25 \%$ group shows a significantly decrease among the exposed groups in liver ALP activities. A decrease was recorded in activities of the ALB in serum of the exposed mice compared to those in the negative control group. In liver ALT, AST and ALP there were a significant $(p<0,05)$ decrease in the activities compared with negative control.

Micronucleus Assay: The frequencies of micronucleated (MN) erythrocytes and other erythrocytes with other abnormalities (enucleated, binucleated, polymorphic, crenated, bud, kidney shape and fragmented) were significant $(p<0.05)$ and dose dependent (Table 2). The frequency of binucleated increased through the concentration and reached a maximum on the $25 \%$ concentration group. Figure 2 shows the frequency of micronuclei and nuclear aberrations in mice exposed to automobile waste leachate while figure 3 shows different types of abnormality induced by the IOASL in mice.

Genotoxicity to Sperm cell: The genotoxicity in the different concentrations of simulated car waste leachate sample on mice sperm, after 35 day period of exposure were shown in Table 3. There was concentration dependent increase in the abnormalities observed 

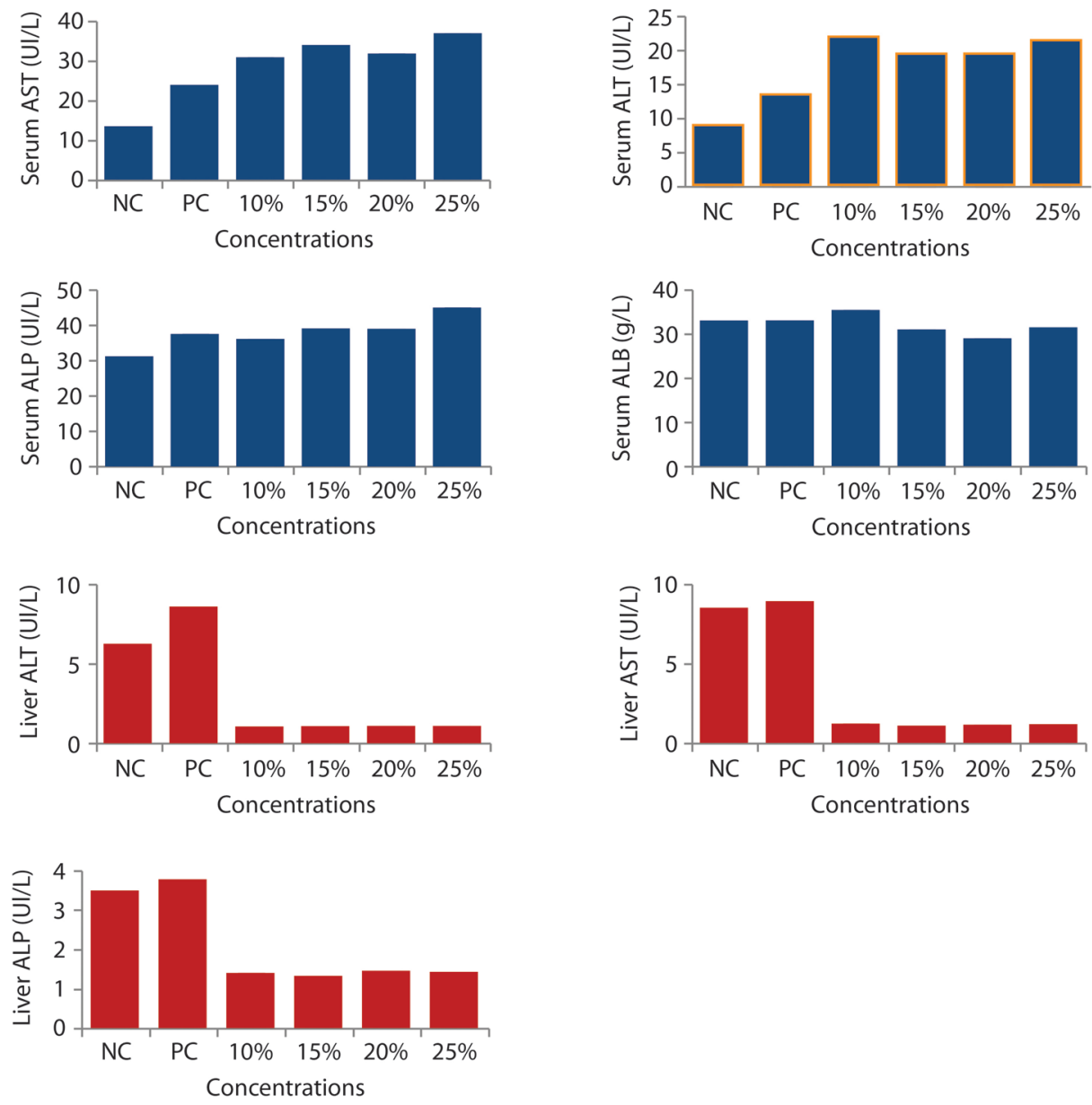

Fig. 1. Effects of IOASL on Serum and Liver AST, ALT, ALP and Albumin Activities in Mus musculus. NC- negative control; PC- positive control. All values are significantly different $(p<0,05)$ compared to negative control.

TABLE 2

Frequency of Micronuclei and Nuclear Abnormalities in mice exposed to IOASL

\begin{tabular}{cccccccccc} 
Conc & Total & MN & EN & BN & CN & PM & KS & FG \\
NC & 22 & $1,67 \pm 0,33^{*}$ & $2,00 \pm 0,00$ & $1,33 \pm 0,33^{*}$ & $0,00 \pm 0,00$ & $0,67 \pm 0,33$ & $0,33 \pm 0,33$ & $1,00 \pm 0,58$ & $0,33 \pm 0,33$ \\
$10 \%$ & 114 & $3,33 \pm 0,33$ & $5,00 \pm 0,00^{*}$ & $8,33 \pm 1,20^{*}$ & $4,00 \pm 0,58^{*}$ & $1,67 \pm 0,67$ & $4,67 \pm 0,88^{*}$ & $4,33 \pm 0,88^{*}$ & $0,67 \pm 0,67$ \\
$15 \%$ & 116 & $5,00 \pm 1,00^{*}$ & $8,33 \pm 2,03^{*}$ & $11,00 \pm 1,73^{*}$ & $5,33 \pm 2,33^{*}$ & $3,33 \pm 0,67^{*}$ & $6,67 \pm 0,88^{*}$ & $5,67 \pm 1,20^{*}$ & $10,00 \pm 2,51^{*}$ \\
$20 \%$ & 194 & $7,33 \pm 0,67^{*}$ & $9,00 \pm 1,53^{*}$ & $12,33 \pm 0,88^{*}$ & $0,67 \pm 0,88^{*}$ & $5,33 \pm 1,76^{*}$ & $7,67 \pm 2,19^{*}$ & $9,67 \pm 2,40 *$ & $6,67 \pm 0,88^{*}$ \\
$25 \%$ & 248 & $11,33 \pm 0,88^{*}$ & $10,00 \pm 1,00^{*}$ & $14,33 \pm 3,18^{*}$ & $9,33 \pm 1,20^{*}$ & $7,67 \pm 2,90^{*}$ & $10,00 \pm 1,73^{*}$ & $11,0 \pm 4,36^{*}$ & $9,33 \pm 0,67^{*}$ \\
PC & 283 & $14,33 \pm 2,60^{*}$ & $2,52 \pm 1,43$ & $15,67 \pm 1,45^{*}$ & $13,00 \pm 0,58^{*}$ & $8,00 \pm 2,00^{*}$ & $10,67 \pm 2,33^{*}$ & $13,00 \pm 0,58^{*}$ & $11,00 \pm 1,00 *$ \\
\hline
\end{tabular}

Conc: Concentration; SD: Standard Deviation NC: Negative Control; BN: Binucleated; PC: Positive Control; PM: Polymorphic; MN: Micronucleus; CN: Creanated; EN: Enucleated; KS: Kidneyshape; FG: Fragmented; BD: Bud; * significantly $(p<0.05)$ different from control; Total number of nuclei scored/ concentration: 3,000. 


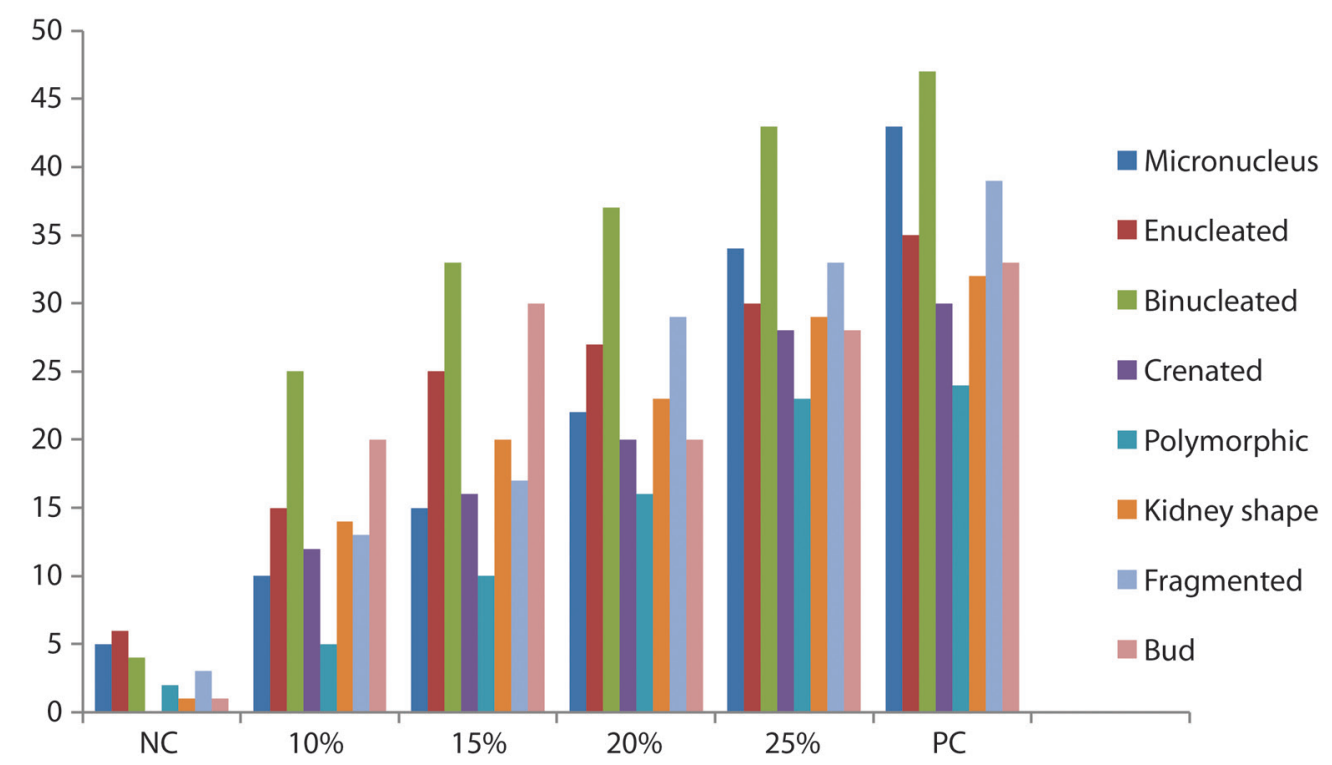

Fig. 2. Frequency of micronuclei and nuclear aberrations in mice exposed to automobile waste leachate.
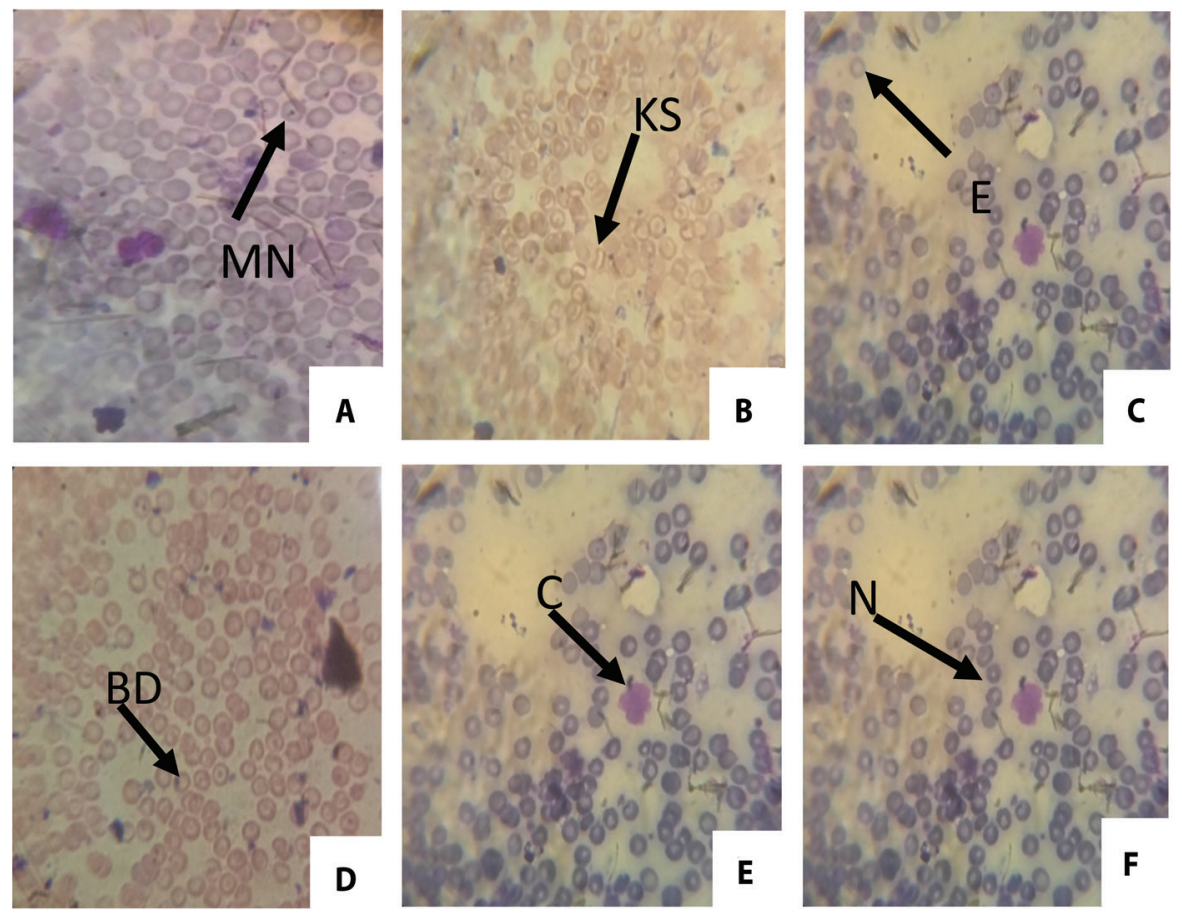

Fig. 3. Different types of abnormality induced by the IOASL in mice MN (Micronucleus); KS (kidney shape); E (Enucleated); BD (Bud); C (Crenated); N (Normal cell). 
TABLE 3

Summary of morphologically abnormal sperm heads induced in Swiss Albino mice by different concentrations of IOASL after 35 day exposure.

\begin{tabular}{cccccc} 
Concentration & $\begin{array}{c}\text { Number } \\
\text { of animals }\end{array}$ & $\begin{array}{c}\text { Total number of } \\
\text { sperm counted }\end{array}$ & $\begin{array}{c}\text { Total number of } \\
\text { abnormalities }\end{array}$ & Frequency & Mean \pm SE \\
$\begin{array}{c}\text { Negative control } \\
\text { (distilled water) }\end{array}$ & 3 & 3000 & 199 & $6,63 \%$ & $64,67 \pm 14,53$ \\
$10 \%$ & 3 & 3000 & 317 & 316 & $10,56 \%$ \\
$15 \%$ & 3 & 3000 & 317 & $10,53 \%$ & $1,04 \mathrm{E} 2 \pm 4,91^{*}$ \\
$20 \%$ & 3 & 3000 & 358 & $11,93 \%$ & $1,02 \mathrm{E} 2 \pm 17,03^{*}$ \\
$25 \%$ & 3 & 3000 & 268 & $8,93 \%$ & $1,24 \mathrm{E} 2 \pm 22,85^{*}$ \\
\hline
\end{tabular}

${ }^{*} \mathrm{P}<0,05=$ levels of significance of abnormal sperms in mice treated with leachate sample compared with the negative control.

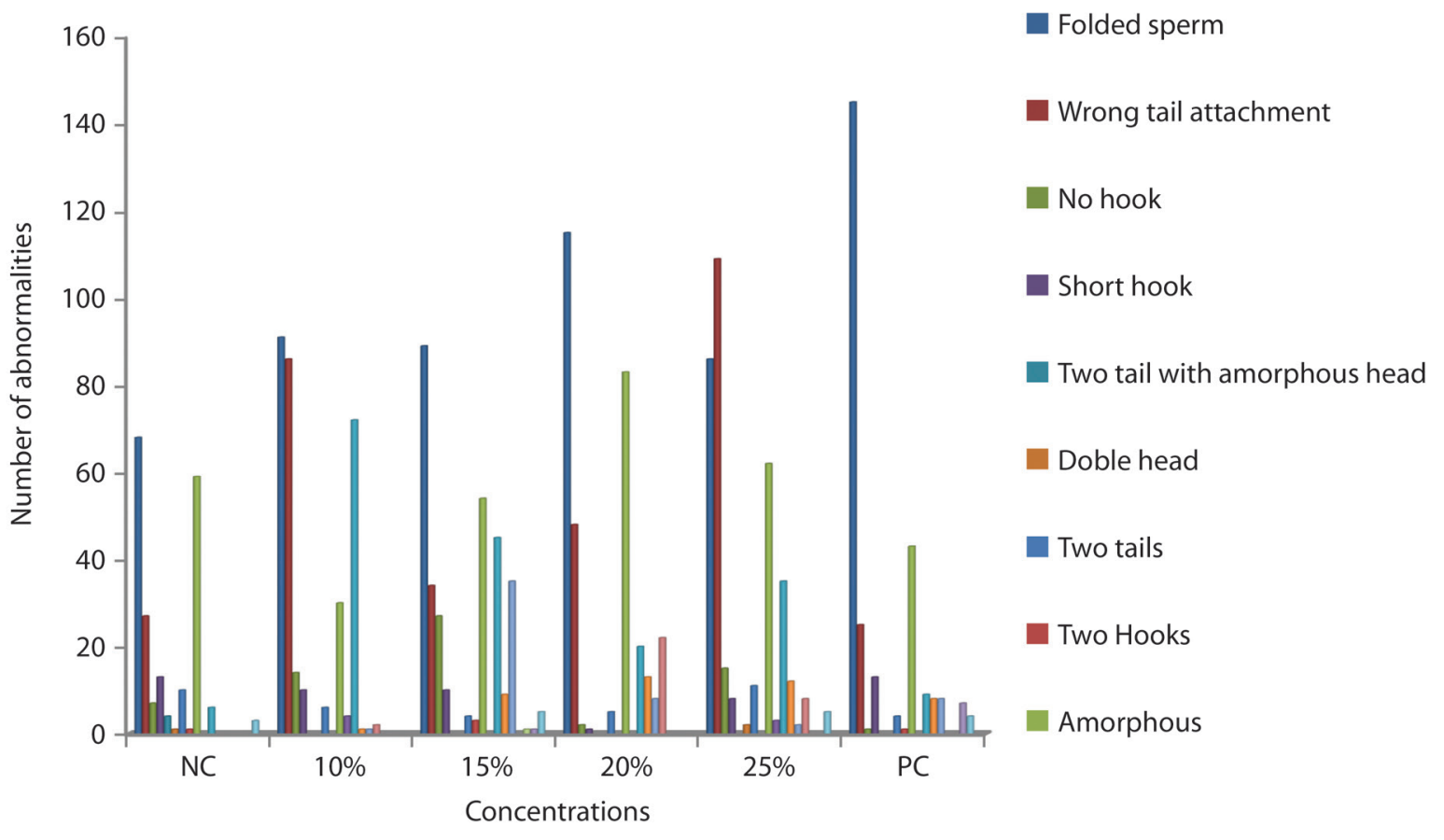

Fig. 4. Mean sperm abnormalities in each group after 35 day of exposure.

which indicate that the leachate sample is statistically significant compared to the negative control (Table 4). The positive control group treated with cyclophosphamide also shows statistical significant level at $(p<0,05)$. Different types of sperm abnormalities were observed. Hypospermy was observed in the positive control group.

The sperm abnormalities observed are shown in figure $5(A-F)$. Fig. 4 present the graphical representation of the abnormalities observed.

\section{DISCUSSION}

Simulated leachate sample contains a mixture of organic and inorganic substances that can react with each other which run-off into ground water (Sang \& Li, 2004). This was confirmed in our result of the physicochemical analysis (Table 1$)$. The $\mathrm{pH}$ value $(6,96-8,33)$ in this study was in consonance with work done by Kanmani and Gandhimathi (2013) and was also within the standard limits. All the heavy metals analyzed in the test sample 

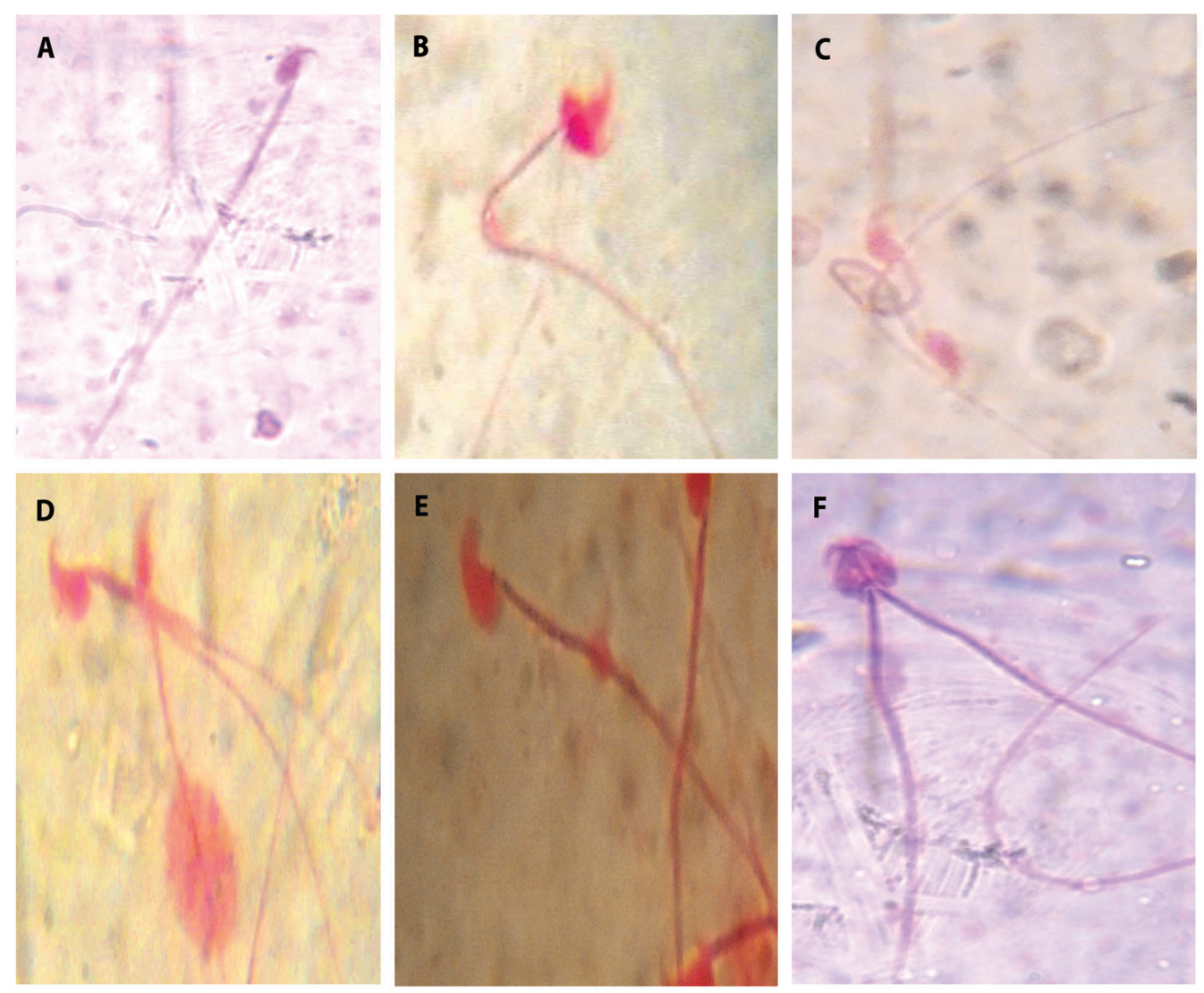

Fig. 5. Abnormal sperm cells in mice exposed to different concentrations of IOASL (A) Normal mouse sperm morphology (B) Sperm with wrong tail attachment (C) Folded sperm (D) Two tails (E) Lack usual hook (F) Fused Head.

(IOAWL) were above the allowable limit (FEPA, 1991; USEPA, 2006; NESREA, 2009) and the high concentrations recorded can be attributed to their stabilized states (Kjeldsen, Barlaz, Rooker Baun \& Ledin, 2002) which is similar to the study carried out by Alimba, Bakare and Latunji (2006). The high level of $\mathrm{Fe}$ and $\mathrm{Pb}$ observed indicate the presence of steel scraps and batteries in the dumpsite respectively (Kanmani \& Gandhimathi, 2013). Thus, the level of heavy metals in the IOAWL may be attributed to presence of batteries, engines oil, steel scraps, coal, older lead-based paints and lead pipes disposed at the dumpsites (CalRecovery, 1982) that Kanmani and Gandhimathi (2013) reported the presence of high concentrations of $\mathrm{Zn}, \mathrm{Cu}$, and $\mathrm{Cd}$ in leachate examined suggesting a strong reducing environment. The exposure of mice to these heavy metals have been reported to result into single strand break in DNA (Banu, Danadeyi, Rahman, Ahuja \& Kaiser, 2001) and induced chromosomal aberrations, micronuclei and single strand break in mammalian cells (Wise, Wise, \& Little, 2002). Thus the abnormalities observed in the sperm and somatic cell in this study may be attributed to the heavy metals recorded.
Serum AST and ALT are the most used biochemical markers of hepatocellular necrosis and are considered sensitive indicators of hepatic injury (Molander, Wroblewski \& La-Due, 1955). Likewise, they have been used as tools to study cell viability, cell death (apoptosis) and changes in cell membrane permeability (Davies, 1992; Dasgupta, Ghosh \& Das, 1996). It is possible that heavy metals, other leachate constituents and their metabolites may have induced oxidative tissue damage in the hepatocytes which led to increase in the cell membrane permeability and may eventually lead to hepatocytic cell death (Stohs \& Bagchi, 1995). The significant decrease in the liver enzymes activities was observed and may be due to hepatic cells injury or leakage into the blood circulation to increase serum enzymes activities making a significant increase in the serum ALT, AST and ALP of mice treated with leachate and similar reports by Adel-Razik and Shehata (2007) that showed possible leakage of enzymes across damaged liver cells to the blood circulation. Alimba, Bakare and Aina (2012) carried out similar study and stated that increase in serum activities of ALT and AST was accompanied by severe 
necrosis, congestion and periportal cellular infiltrations of the liver tissues.

Albumin is a major blood protein responsible for maintaining osmotic pressure in the blood. The dose dependent decrease recorded in the serum albumin level in leachate treated mice may indicate disorders in protein synthesis, metabolism and necrosis as a result of interactions of the complex chemicals, such as heavy metals and other constituents of the tested samples. Metals in their ionic forms, bind to albumin and plasma proteins thereby affecting their metabolic processes and/or transport to the kidney tubules (Goldwasser \& Feldman, 1997). The decrease in concentration of albumin in mice serum treated with leachate could be associated to the decrease earlier recorded in the liver enzymes, this is because the liver is the site for albumin synthesis therefore the deterioration of liver could be the reason for a setback in albumin production. It has been similarly reported by Morowati (2001) where decrease in serum albumin was associated with hepatocellular damage. Decrease in serum albumin may also be due to free radical formation which caused protein damage or protein degradation through oxidative stress induction in rats (Li, Hua, Zhou, Zhang \& Li, 2010).

The result of micronucleus analysis shows that there was a concentration dependent difference in the frequency of nuclear abnormalities. Studies indicated that the increase in binucleated cells implies the cytogenotoxic effect of landfill leachates (Fenech et al., 2003). This is also in consistence with similar observations by Talapatra and Banerjee (2007) that the induction of micronucleus and nuclear lesions in the fishes they used was significantly different when compared with control.

The induction of morphological aberration in sperm morphology by the leachate test sample observed in this study was seen to be concentration dependent and statistically significant $(P<0,05)$ at all concentrations when compared to negative control. The observed abnormalities imply that the IOAWL has genotoxic effect on the sperm cells which might occur during the early stages of spermatogenesis. Our result is in line with the result of Alabi et al. (2013).

The clinical sign and symptoms observed revealed that car waste leachate are harmful to the organs and system of animals. Clinical sign and symptoms observed before the sacrifice of the mice were loss of appetite and diarrhoea, thus this corresponds to that recorded by Alimba, Bakare and Aina (2012) which was observed in rats. Long term exposures to dumpsites are injurious to the brain structures and also induce behavioural changes (Ijomone, Olayemi, Olaibi, Esomonu \& Nwoha, 2015).
Reduced activities, sluggish movement and leg paralysis revealed in this study indicated a nervous system disorder which is associated with presence of heavy metals in the leachate sample was earlier reported by (European commission, 2002). This observation in nervous system disorder was also buttressed by ljomone, Olayemi, Olaibi, Esomonu and Nwoha (2015) in their findings, which revealed that rats exposed to refuse dump sites present alterations in the cerebella white and degenerative changes in the cells. The physicochemical and heavy metal analysis of the tested leachate contained some inorganic anions that may induce the various forms of abnormalities recorded.

This study shows that automobile waste leachate (AWL) contains some chemical and physical parameters that may induce genotoxic effect on sperm morphology and nuclear abnormality of the mice as well as, alterations in enzymes activities. The abnormalities observed in the test groups were concentration dependent compared to the negative control. The alterations recorded in the sperm morphology analysis were statistically significant as the abnormalities observed almost doubled that of the negative control group. Automobile waste constituents can either directly or indirectly get into the human body by dermal contact, inhalation or through consumption of drinking water. Therefore, human populations living near this site and those exposed through occupation are at higher risk of developing any of the health related issues discussed above. Hence, there is need for a campaign on mass awareness, better policy measures for managing car waste and for ensuring safety of people living in that area.

The low level of awareness of the dangers associated with exposure to metals and toxic chemical components of the automobile waste to the workers and the inhabitants living near the site triggered this work. Similarly, no work has been carried out on the genotoxic potential of car wastes using mice in a large mechanic workshop like that of Ipata Oloje in Ilorin, Kwara State. Thus, appropriate steps can be taken on car waste management to help educate the public on how to guard themselves against its toxic effect.

\section{REFERENCES}

Adel-Razik, H. F., \& Shehata, E. M. S. (2007). Comparative histopathological and histochemical studies on IGR, Lufenron and Profenfos insecticide in Albino Rats. Journal of Applied Sciences Research, 3(5), 577.

Adelekan, B. A., \& Abegunde, K. D. (2011). Heavy metals contamination of soil and ground water at automobile 
mechanic villages in Ibadan, Nigeria. International Journal of Physical Sciences, 6(5), 1045-1058.

Alabi, O. A., Omosebi, O., \& Chizea, I. (2013). Determination of the mutagenic and genotoxic potential of simulated leachate from an automobile workshop soil on eukaryotic system. Toxicology and industrial health, 1(1), 9.

Alimba, G. C., Bakare, A. A., \& Aina, O. O. (2012). Histopathological Effect of Liver and Kidney of Rats Treated with Leachate from Aba-Eku Landfill: Resources and Environment, 2(4), 150-163.

Alimba, G. C., Bakare, A. A., \& Latunji, C. A. (2006). Municipal Landfill Leachate induced Chromosome Aberration in Rat Bone Marrow Cells. African Journal of Biotechnology 5, 2053-2057.

Alimba, C. G. (2013). DNA and systemic damage induced by land fill leachates and health impacts of human exposure to landfills in Lagos and Ibadan, Nigeria (Ph.D thesis). Department of Zoology, University of Ibadan, Nigeria.

APHA. (1998). Standard Methods for the examination of water and waste water. American Public Health Association, Washington, DC, USA.

Banu, B. S., Danadevi, K., Rahman, M. F., Ahuja, Y. R., \& Kaiser, J. (2001). Genotoxic effect of Monocrotophos to sentinel species using comet assay. Food Chemical Toxicology, 39, 361-366. doi: 10.1016/S0278-6915(00)00141-1

Bakare, A. A., Oshode, K. A., \& Adelodun, A. T. (2007). Paraccetamol and caffeine induced sperm shape abnormalities in mice. African Journal of Animal Biomedical Science, 2, 11-16

Bakare, A. A., Alimba, C. G., \& Alabi, O. A., (2013a). Genotoxicity and mutagenicity of solid waste Leachate: A review: African Journal of Biotechnology, 12(27), 4206-4220. doi: 10.5897/AJB2013.12014

Bakare, A. A., Alabi, O. A., Gbadebo, A. M., Ogunsuyi, O. I., \& Alimba, C. G. (2013b). In Vivo Cytogenotoxicity and Oxidative Stress Induced by Electronic Waste Leachate and Contaminated Well Water. Challenges, 4, 169-187.

Bakare, A. A., Udoakang A. J., Anifowoshe, A. T., Fadoju, O. M., Ogunsuyi, O. I., Alabi, O. A., Alimba, C. G., \& Oyeyemi, I. T. (2016). Genotoxicity of Titanium Dioxide Nanoparticles using the Mouse Bone Marrow Micronucleus and Sperm Morphology Assays. Journal of Pollution Effect and Control, 4, 156.

Bartke, A. J. Weir, A. Mathison, P., Robertson, C., \& Dalterio, S. (1974): Testicular function in mouse strains with different age of sexual maturation. Journal of Hereditary, 65, 204-208. doi: 10.1093/oxfordjournals.jhered.a108504

Bjerg, P. L., Albrechtsen, H. J., Kieldsen, P., Christensen, T. H., Cozzarelli, I. M., \& Heinrich, D.H. (2003). The Groundwater Geochemistry of Waste Disposal Facilities, in (ed.), Treatise on Geochemistry. Pergamon Oxford, 579-612. doi: 10.1016/B0-08-043751-6/09057-5
CalRecovery. (1982). Inc., Metro Manila Solid Waste Management Study - Waste Stream Characterization, prepared for Ad Hoc Committee, Republic of the Philippines.

Carrasco, K. R., Tilbury, K. L., \& Myers, M. S. (1990). Assessment of the piscine micronucleus test as in situ biological indicator of chemical contaminant effects. Canadian Journal of Fisheries and Aquatic Sciences, 47, 2123-2136. doi: 10.1139/f90-237

Christensen, T. H., Kieldsen, P., Bjerg, P. L., Jensen, D. L., Christensen, J. B., Baun, A., Albrechten, H. J., \& Heron, C. (2001). Biochemistry of landfill leachate plumes. Applied Geochemistry, 16, 659-718. doi: 10.1016/ S0883-2927(00)00082-2

CIOMS (1985). International Guiding Principles for Biomedical Research Involving Animals. Altern Lab Anim, PMID, 11653736

Dasgupta, S., Ghosh, S., \& Das, K. K. (1996). Transamine activities in some metabolically active tissues in nickel-treated rats under protein restriction; Indian Journal of Physiology and. Allied Sciences, 50, 27-33.

Davies, D. T. (1992). Enzymology in preclinical safety evaluation. Toxicologic Pathology, 20, 501-505. doi: $10.1177 / 0192623392020003207$

Doumas, B. T., Watson, W. A., \& Biggs, H. C. (1971). Albumin standards and Management of serum albumin with bromocresol green. Clinica Chimica Acta, 31, 87-96. doi: 10.1016/0009-8981(71)90365-2

Duruibe, J. O., Ogwuegbu, M. O. C., \& Egwurugwu, J. N. (2007). Heavy metal pollution and human biotoxic effects. International Journal of Physical Sciences, 2(5), 112-118.

El-Fadel, M., Findikakis, A. N., \& Leckie, J. O. (1997). Environmental impacts of solid waste landfilling. Journal of Environmental Management, 50, 1-25. doi: 10.1006/ jema.1995.0131

Emma, S., (2013). Solid Waste Management and Health Effect. (Degree thesis). Environmental and HealthProtection.15 ECTS.

European commission (2002). DG.ENV:E3: Heavy metals in waste environmental impacts of Mining in Eastern Washington. Center for Water and Watershed Studies Fact Sheet University of Washington, Seattle, USA.

Fenech M., Chang, W. P., Kirsch-Volders, M., Holland, N., Bonassi, S., \& Zeiger, E. (2003). HUMN project: detailed description of the scoring criteria for the cytokinesis-block micronucleus assay using isolated human lymphocyte cultures. Mutation Research 534, 65-75. doi: 10.1016/ S1383-5718(02)00249-8

FEPA (1991). Guidelines and Standards for Environment Pollution Control in Nigeria. Federal environmental protection agency, Federal Republic of Nigeria.

Goldwasser, P., \& Feldman J. (1997). Association of serum albumin and mortality risk; Journal of Clinical Epidemiology, 50, 693-703. doi: 10.1016/S0895-4356(97)00015-2 
Ijomone, O. M., Olayemi K., Olaibi, O. K., Esomonu, U. G., \& Nwoha, P. U. (2015). Hippocampal and striatal histomorphology following chronic nicotine administration in female and male rats. Annals of Neurosciences, 22, 1.doi: 10.5214/ans.0972.7531.220107

Kanmani, S., \& Gandhimathi, R. (2013). Assessment of heavy metal contamination in soil due to leachate migration from an open dumping site. Applied Water Science, 3(1), 193-205.doi: 10.1007/s13201-012-0072-z

Kjeldsen, P., Barlaz, M. A., Rooker, A. P., Baun, A., Ledin, A., \& Christensen, T. H. (2002). Present and long term composition of MSW landfill leachate: A review. Critical Review Environmental Science and Technology, 32(4), 297-336. doi: 10.1080/10643380290813462

Li, W., Hua, T., Zhou, Q., Zhang, S., \& Li, F. (2010) Treatment of stabilized landfill leachate by the combined process of coagulation/ flocculation and powder activated carbon adsorption. Desalination, 264, 56-62. doi: 10.1016/j. desal.2010.07.004

Morowati M. (2001). Biochemical and histopathological changes in serum creatine and kidney induced by inhalation of Thimet (phosphate) in male Swiss Albino mouse, Mus musculus; Environmental Research, 87, 31-36.doi: 10.1006/enrs.2001.4285

Molander, D. W., Wroblewski, F., \& La-Due, J. S. (1955). Transaminase compared with cholesterase and alkaline phosphatase an index of hepatocellular integrity. Clinical Research, 3, 20-24.
NESREA (2009). Laws and regularions. Retrieved from http:// www.nesrea.gov.ng/publications-downloads/ laws-regulations/

Oshode, O. A., Bakare, A. A., Adeogun, A. O., Efuntoye, M. O., \& Sowunmi, A. A. (2008) Exotoxicological assessment using Clarias gariepinus and microbial characterization of leachate from municipal solid waste landfill. International Journal Of environmental Resources, 2(4), 391-400.

Peplow, D. (1999). Chemical and Biological Indicators of Mine Effluent Impacts on Alder Creek in the North Cascade Mountains, Washington (Masters Thesis). University of Washington, Seattle, Washington, USA.

Stohs, S. J., \& Bagchi, D. (1995). Oxidative mechanisms in the toxicity of metals ions. Free Rad. Biol. Med, 18, 321-336. doi: 10.1016/0891-5849(94)00159-H

Talapatra, S. N., \& Banerjee, S. K. (2007). Detection of micronucleus and abnormal nucleus in erythrocytes from the gill and kidney of Labeo bata cultivated in sewage-fed fish farms. Food Chemical Toxicology, 45, 210-215. doi: 10.1016/j.fct.2006.07.022

United States Environmental Protection Agency (USEPA) (1996). Acid digestion of sediments, sludges and soils, Method3050B.USEPA, Washington, DC, USA.

Wise, J. P., Wise, S. S., \& Little, J. E. (2002). The cytotoxicity and genotoxicity of particulate and soluble hexavalent chromium in human lung cells. Mutation Research, 517, 221229. doi: 10.1016/S1383-5718(02)00071-2 